\title{
General properties of water of Baidya fish pond, Tankisinwari, Nepal
}

\author{
Ganesh Bahadur Thapa ${ }^{1}$ and Joydeb Pal $^{2}$ \\ ${ }^{1}$ Department of Biology, Central Campus of Technology, Tribhuvan University, Dharan, Nepal \\ ${ }^{2}$ Department of Zoology, Universiy of North Bengal, Siliguri- 734013, West Bengal, India \\ E-mail: gthapast@yahoo.com
}

\begin{abstract}
In the present study, ranges and correlation among different physicochemical parameters viz., air temperature, water temperature, $\mathrm{pH}$, turbidity, total dissolved solids, conductivity, dissolved carbon dioxide, ammonia, nitrate, dissolved oxygen, biological oxygen demand, chloride, total alkalinity, total hardness and phosphate were taken into consideration. The water quality of Baidya fish pond was normal except high fluctuation of chloride $1 \pm 0.241$ to $29.84 \pm 0.260 \mathrm{mg} / \mathrm{l}$ and ammonia $1.55 \pm 0.088$ to $18.7 \pm 0.061 \mathrm{mg} / \mathrm{l}$ during manuaring period and casual addition of wastes like toilet cleaners, caustic potash etc. Outbreak of epizootic ulcerative syndrome (EUS) was observed at the periphery of Baidya fish farm during winter months when polluted cold water from Koshi canal was added. The affected fishes developed several lesions around the body and fin rot. Due to sudden fall in dissolve oxygen, less than $4 \mathrm{mg} / \mathrm{l}$ during April and May, 2010 mass mortality of fishes Labeo rohita, Cirrhina mrigala, Hypothalamichthys molitrix, Aristichthys nobilis occurred. When chicken droppings were added in pond, ammonia was raised up to $18.7 \mathrm{mg} / \mathrm{l}$ which led to mass mortality of fish (Pangasius) during August.
\end{abstract}

Key words: Physico-chemical properties of water, Baidya fish pond, Itahari, Nepal

\section{Introduction}

Nepal has about 6,000 rivers and their tributaries, several lakes, swamps, ponds and streams distributed throughout the country. The total water bodies occupy $2.8 \%$ of total area of the country. Natural water bodies consist of about $55 \%$ of total inland water resources and these water bodies support about 201 indigenous fish species (Shrestha, 2001; Shrestha, 2008). Though the potentiality of the extension of fish farming is very high, capture fisheries contribute much more $(16700 \mathrm{MT} / \mathrm{yr})$ than the production of cultured fish (10559 MT/yr) and total shares of fisheries to GDP is $0.81 \%$ (DOFD, 2007).

The physico-chemical parameters of water bodies influence directly or indirectly (the number, varieties, distribution, metabolic activities, growth etc.) of the aquatic organisms in various ways. Functioning of the aquatic ecosystem is regulated by the interaction among the physico-chemical and biological components of the system. Hence, it is essential to have the knowledge of physico-chemical parameters of water bodies for aquaculture.

Reid (1961) has stated that the successful development and maintenance of a population of organisms depends upon harmonious ecological balance between environmental conditions 
and tolerance of the organism to variations in one or more of these conditions. The physicochemical parameters of a water body change due to seasonal change, diurnal changes and pollutants. These bring significant seasonal and diurnal change in abundance of aquatic organisms. Among the physico-chemical parameters air temperature, water temperature, transparency, $\mathrm{pH}$, dissolved oxygen, free carbon dioxide, alkalinity, hardness, chloride and BOD mainly determine the hydrological condition of water body. Extensive works have been done by different workers on the physico-chemical and biological parameters of freshwater bodies in other countries (Bhowmik, 1988; Dobriyal \& Singh, 1989; Patralekh, 1994; Singh \& Singh, 1995; Mishra et al., 1998; Hossain et al., 2007) but very few works have been done in Nepal. Lohaman et al. (1988) studied pre and post monsoon limnological characteristics of lakes of Pokhara and Kathmandu valleys and reported low alkalinity and conductivity in those lakes.

Mc Eachern (1994) reported $8.4 \mathrm{pH}, 0.03 \mathrm{mg} / \mathrm{l}$ phosphate and $8.5 \mathrm{mg} / \mathrm{l}$ dissolved oxygen in Narayani, a lowland (<1000 m) river of Nepal. Aryal and Lacoul (1996) reported high pH, total hardness and BOD at polluted site in Punyamati river. Ormerod et al. (1996) reported $\mathrm{pH}$ range between 7.3 to 8 , chloride $0.4 \mathrm{mg} / \mathrm{l}$ to $1.4 \mathrm{mg} / \mathrm{l}$, nitrate $0.06 \mathrm{mg} / \mathrm{l}$ to $0.28 \mathrm{mg} / \mathrm{l}$, and phosphate $0.02 \mathrm{mg} / \mathrm{l}$ to $0.04 \mathrm{mg} / \mathrm{l}$ from the highland (>2000 m) rivers of Nepal.

Shrestha et al. (2009) reported that the water quality parameters of Tamor river viz. air temperature $\left(22-26.3^{\circ} \mathrm{C}\right)$, water temperature $\left(16.0-19.0^{\circ} \mathrm{C}\right)$, dissolve oxygen $(9.7-10 \mathrm{ppm})$, $\mathrm{pH}$ (7.3-7.5), alkalinity (17.1 mg/l), total hardness (28.5-34.2 mg/l), $\mathrm{CO}_{2}(5 \mathrm{mg} / \mathrm{l})$ and conductivity $(37.7-56.7 \mu \mathrm{s} / \mathrm{cm})$ were within the suitable range for cold water fishes. Niroula et al. (2010) have reported higher $\mathrm{pH}$, conductivity, turbidity, total phosphorus and total alkalinity in summer whereas total dissolved solids, nitrate, total hardness- $\mathrm{CaCo}_{3}$, dissolve oxygen, BOD and chloride content were higher in winter, although, water depth, temperature, ammonia and carbon dioxide were found to be higher in rainy season in Betana pond, eastern Nepal.

Present study area $\left(900 \mathrm{~m}^{2}\right)$ includes a large commercial pond of Baidya fish farm located at latitude $26^{\circ} 31^{\prime} 12.00^{\prime \prime} \mathrm{N}$ and longitude $87^{\circ} 16^{\prime} 19.86^{\prime \prime} \mathrm{E}$ along the industrial corridor of Tankisinwari, Morang district. The present study deals with variation in physic-chemical parameters pond water viz., air temperature, water temperature , $\mathrm{pH}$, turbidity , total dissolved solids, dissolved carbon dioxide, ammonia, nitrate, dissolved oxygen, biological oxygen demand, chloride, total alkalinity, total hardness and phosphate during November, 2008 to October, 2010.

\section{Methodology}

The physic-chemical parameters of Baidya fish pond were analysed as per the methods of Trivedi and Goel (1984) and APHA (2005). DO, pH, temperature and $\mathrm{CO}_{2}$ were studied on the spot and other parameters were analyzed in the laboratory by carrying water samples in closed bottles. Sampling was done at 8.00-11.0 a.m. in the last week of each month. Monthly data of different parameters were pooled into seasonal data (summer from March to June, rainy from July to October and winter from November to February). Infected fishes from the study site were also collected. Standard deviation and correlation coefficient were calculated by using Microsoft excel statistical function of computer software. The correlation coefficient between different variables was calculated and their significance difference was tested using SPSS. 


\section{Results and Discussion}

\section{Air temperature}

The minimum air temperature was $20 \pm 0.132^{\circ} \mathrm{C}$ in December and maximum $33 \pm 0.325^{\circ} \mathrm{C}$ in April during the first year study period (Tab. 1). Similar pattern of air temperature was observed in the second year study period also. The maximum air temperature was $32.5 \pm 0.497^{\circ} \mathrm{C}$ in March and minimum $19 \pm 0.452^{\circ} \mathrm{C}$ in January during the second year study period (Tab. 2). The air temperature had positive and significant correlation with water temperature $(\mathrm{r}=0.935, \mathrm{P}<0.01)$, and biological oxygen demand $(\mathrm{r}=-0.579, \mathrm{P}<0.05)$ and ammonia $(\mathrm{r}=0.671, \mathrm{p}<0.05)$ but inverse and significant correlation with $\mathrm{pH}(\mathrm{r}=-0.614$, $\mathrm{P}<0.05)$, nitrate $(\mathrm{r}=-.615, \mathrm{p}<0.05)$ and free carbon dioxide $(\mathrm{r}=-0.763, \mathrm{P}<0.01)$.

Table 1. Monthly variation in the physico-chemical parameters of water of Baidya fish farm (Nov., 2008 - Oct., 2009).

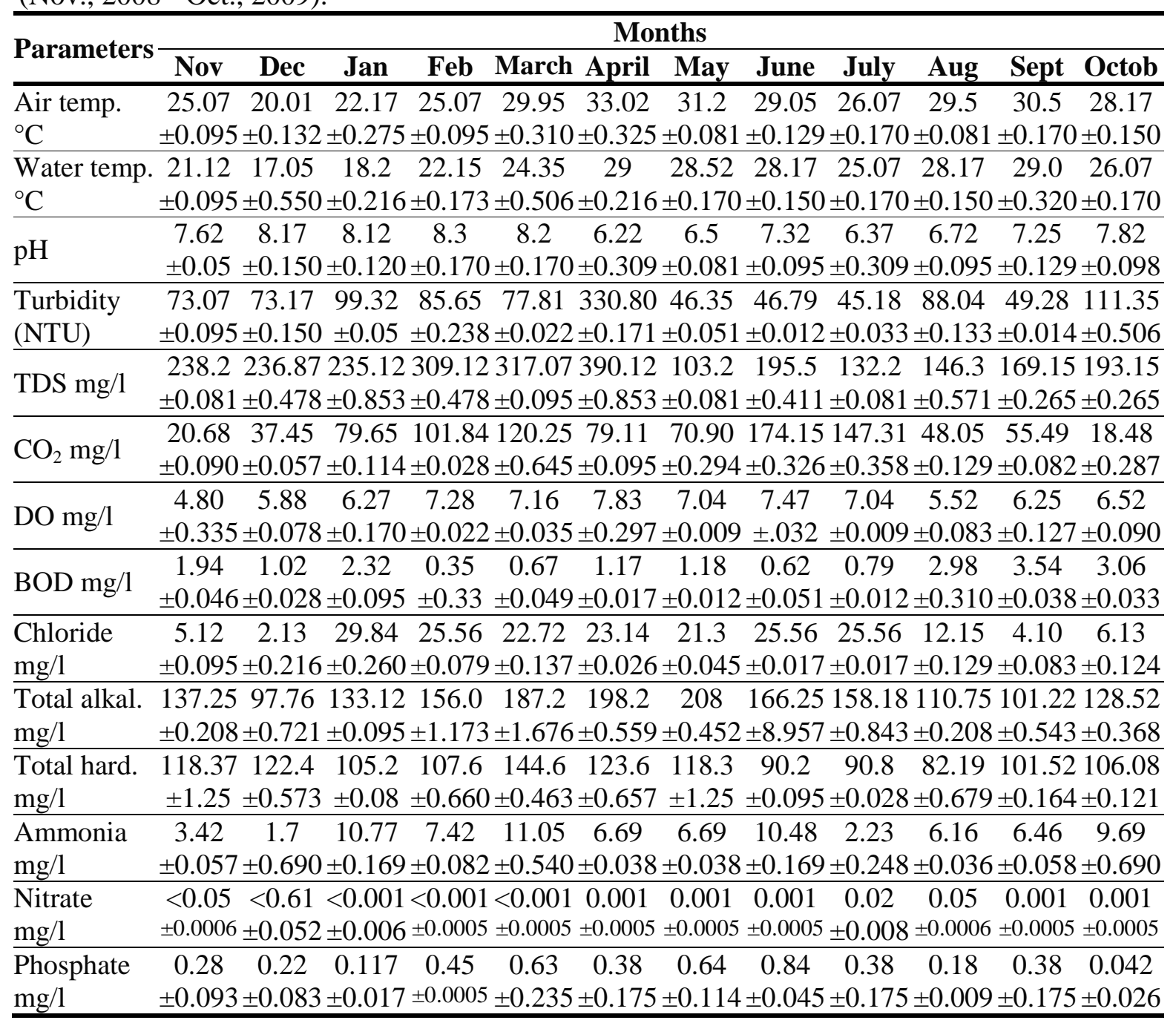

\section{Water temperature}

The lowest surface water temperature was $17.0 \pm 0.550^{\circ} \mathrm{C}$ in December and highest $29 \pm 0.320^{\circ} \mathrm{C}$ in September during the first year (Tab. 1) and the minimum temperature was $17.0 \pm 0.452^{\circ} \mathrm{C}$ in January and the highest $31 \pm 0.327^{\circ} \mathrm{C}$ in September during second year 
study period (Tab. 2). The water temperature had positive and significant correlation with air temperature $(\mathrm{r}=0.935, \mathrm{P}<0.01)$ and phosphate $(\mathrm{r}=0.610, \mathrm{P}<0.01)$, but inverse and significant correlation with $\mathrm{CO}_{2}(\mathrm{r}=-0.755, \mathrm{P}<0.01), \mathrm{pH}(\mathrm{r}=-0.725, \mathrm{P}<0.01)$, dissolved oxygen $(\mathrm{r}=-0.710, \mathrm{P}<0.01))$ and total hardness $(\mathrm{r}=-0.909, \mathrm{P}<0.01)$.

Table 2. Monthly variation in the physico-chemical parameters of water of Baidya fish farm (Nov., 2009 - Oct., 2010).

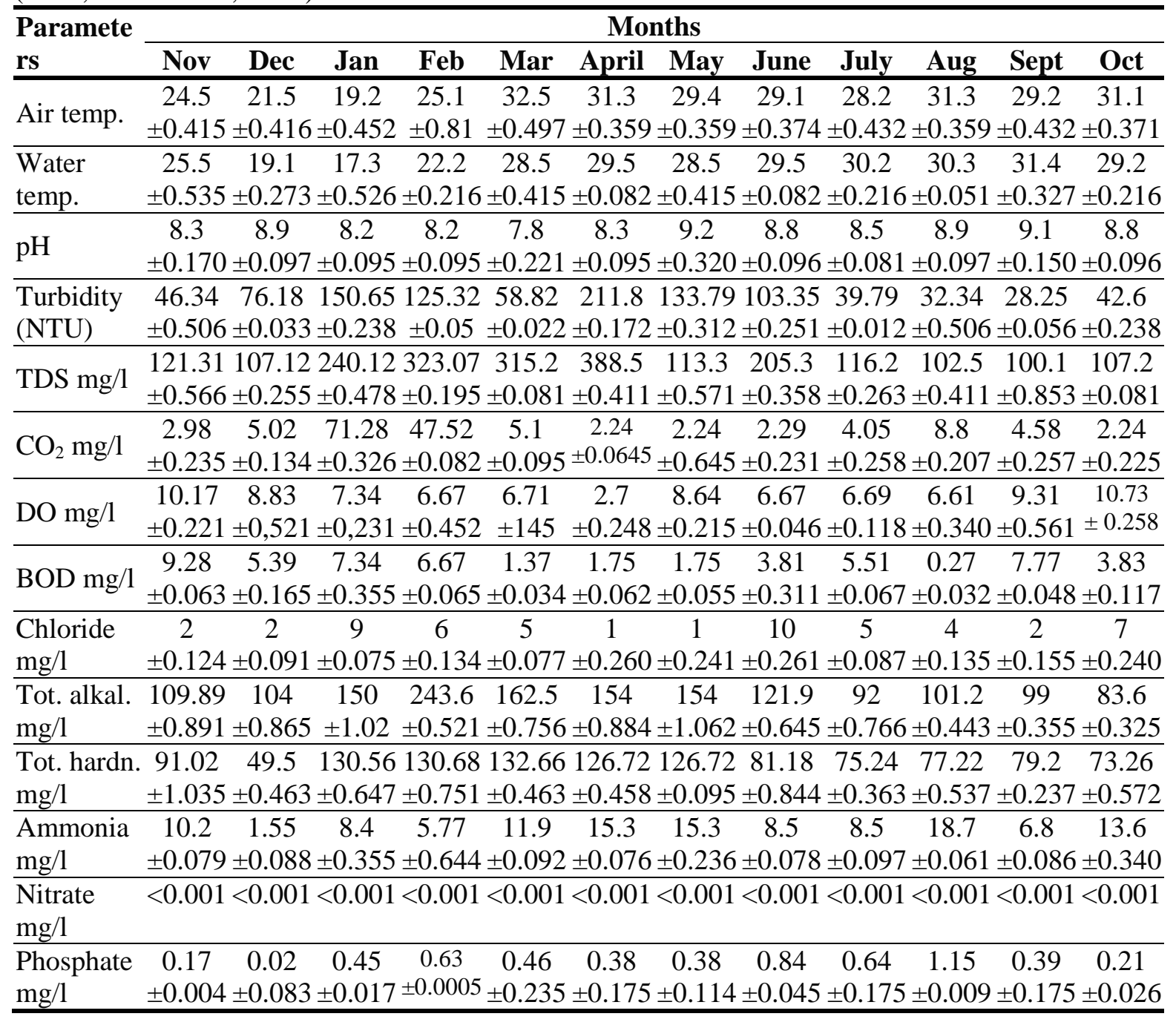

\section{$p H$}

The $\mathrm{pH}$ of water was minimum i.e., $6.3 \pm 0.309$ in April/July and $7.8 \pm 0.221$ in March and maximum i.e., $8.3 \pm 0.12$ in February and $9.2 \pm 0.32$ in May (Tabs. 1, 2). pH had positive and significant correlation with DO $(\mathrm{r}=0.594, \mathrm{P}<0.05)$ and total alkalinity $(\mathrm{r}=0.993, \mathrm{P}<0.01)$, free $\mathrm{CO}_{2}(\mathrm{r}=0.594, \mathrm{P}<0.05)$ and $\mathrm{BOD}(\mathrm{r}=0.857, \mathrm{P}<0.01)$ but inverse and significant correlation with nitrate $(\mathrm{r}=-0.675, \mathrm{p}<0.05)$.

\section{Dissolved oxygen}

The dissolved oxygen was maximum $(7.83 \pm 0.297 \mathrm{mg} / \mathrm{l})$ at the end of April and minimum $(4.82 \pm 0.335 \mathrm{mg} / \mathrm{l})$ in November during the first year (Tab. 1). In the second year, the maximum DO $(10.73 \pm 0.258 \mathrm{mg} / \mathrm{l})$ occurred in November and minimum $(2.7 \pm 0.248 \mathrm{mg} / \mathrm{l})$ 
in June (Tab. 2). The DO showed positive and significant correlation with total alkalinity $(\mathrm{r}=0.715, \mathrm{P}<0.05)$, Phosphate $(\mathrm{r}=0.577, \mathrm{P}<0.05)$ and total hardness $(\mathrm{r}=0.915, \mathrm{P}<0.05)$ but inverse and significant correlation with free $\mathrm{CO}_{2}(\mathrm{r}=-0.839, \mathrm{P}<0.01), \mathrm{BOD}(\mathrm{r}=-0.398$, $\mathrm{P}<0.05)$, temperature of air $(\mathrm{r}=-0.608, \mathrm{p}<0.05)$, temperature of water $(\mathrm{r}=-0.710, \mathrm{P}<0.01)$.

\section{Free carbon dioxide}

The free carbon dioxide decreased from June to October then increased during the first year and the second year study periods. The maximum free $\mathrm{CO}_{2}$ was $174.15 \pm 0.326 \mathrm{mg} / \mathrm{l}$ in June and minimum $18.48 \pm 0.287 \mathrm{mg} / \mathrm{l}$ in April during the first year (Tab. 1). In the second year, maximum $\mathrm{CO}_{2}(71.28 \pm 0.326 \mathrm{mg} / 1)$ was recorded in January. Free carbon dioxide showed positive and significant correlation with BOD $(\mathrm{r}=0.839, \mathrm{P}<0.01)$ and turbidity $(\mathrm{r}=0.760, \mathrm{P}<0.01)$ but inverse and significant correlation with chloride $(\mathrm{r}=-0.596$, $\mathrm{P}<0.05)$ and total alkalinity $(\mathrm{r}=-0.971, \mathrm{P}<0.05)$.

\section{Total alkalinity}

The maximum total alkalinity was $208 \pm 0.45 \mathrm{mg} / \mathrm{l}$ in April and minimum $97.76 \pm 0.721$ $\mathrm{mg} / \mathrm{l}$ in December during the first year study period (Tab. 1). It had positive and significant correlation with turbidity $(\mathrm{r}=0.598, \mathrm{P}<0.05)$, total hardness $(\mathrm{r}=0.915, \mathrm{P}<0.05)$ and chloride $(\mathrm{r}=0.578, \mathrm{P}<0.05)$ but inverse and significant correlation with biological oxygen demand $(\mathrm{r}$ $=-0.705, \mathrm{P}<0.05)$.

\section{Total hardness}

The maximum total hardness was $144.02 \pm 0.463 \mathrm{mg} / \mathrm{l}$ in March and minimum $82.08 \pm 0.679$ $\mathrm{mg} / \mathrm{l}$ in August during the first year (Tab. 1). It had positive and significant correlation with TDS $(r=0.635, \mathrm{P}<0.05)$, turbidity $(\mathrm{r}=0.650, \mathrm{P}<0.05)$ and total alkalinity $(\mathrm{r}=0.915, \mathrm{P}<0.05)$ and inverse and significant correlation with air temperature $(\mathrm{r}=-0.671, \mathrm{P}<0.05)$, water temperature $(\mathrm{r}=-0.909, \mathrm{P}<0.01)$ and phosphate $(\mathrm{r}=-0.608, \mathrm{P}<0.05)$.

\section{Chloride}

The maximum chloride was $29.82 \pm 0.260 \mathrm{mg} / \mathrm{l}$ in January and minimum $2 \pm 0.216 \mathrm{mg} / \mathrm{l}$ in December during the first (Tab. 1) and maximum $10 \pm 0.261 \mathrm{mg} / \mathrm{l}$ in June and minimum $1 \pm 0.260 \mathrm{mg} / \mathrm{l}$ in April/May of second year study period (Tab. 2). It had positive and significant correlation with carbon dioxide $(\mathrm{r}=0.647, \mathrm{P}<0.05)$ and total alkalinity $(\mathrm{r}=$ $0.578, \mathrm{P}<0.05)$ and inverse and significant correlation with BOD $(\mathrm{r}=-0.640, \mathrm{P}<0.05)$.

\section{Biological oxygen demand}

The biological oxygen demand decreased from July to January and increased from February to May. The maximum biological oxygen demand was $3.52 \pm 0.062 \mathrm{mg} / \mathrm{l}$ in September and minimum $0.32 \pm 0.042 \mathrm{mg} / \mathrm{l}$ in February during the first (Tab. 1) and maximum $9.28 \pm 0.063$ $\mathrm{mg} / \mathrm{l}$ in November and minimum $0.27 \pm 0.032 \mathrm{mg} / \mathrm{l}$ in August in the second year study period (Tab. $2)$. It had positive and significant correlation with turbidity $(\mathrm{r}=0.663, \mathrm{P}<0.05), \mathrm{pH}(\mathrm{r}=0$. 988, $\mathrm{P}<0.01)$ but inverse and significant correlation with $\mathrm{CO}_{2}(\mathrm{r}=-0.654, \mathrm{P}<0.05)$, phosphate $(\mathrm{r}=-0.630, \mathrm{P}<0.05)$, dissolved oxygen $(\mathrm{r}=-0.579, \mathrm{P}<0.05)$ and total alkalinity $(\mathrm{r}$ $=-0.621, \mathrm{P}<0.05)$.

Various physicochemical factors such as water temperature, alkalinity, ammonia, free $\mathrm{CO}_{2}$, $\mathrm{DO}, \mathrm{pH}$ and total hardness have strong influence on fish health and their resistance against the disease causing agents (Shrestha, 1994). Poor condition of physicochemical properties of 
water is $\mathrm{O}_{2}$ depletion, excess ammonia, excess $\mathrm{CO}_{2}$ in water and temperature change. Hossain et al. (2007) have reported that changes in water quality parameters result in stress in the fishes, making them more susceptible to parasitic attacks and diseases.

The air temperature of the study site was higher in summer than in rainy season in the first and second year study period and the lowest temperature was recorded in winter in the second year. The water temperature of Baidya fish farm was higher in summer in first year and in rainy seasons in the second year (Tab. 3). Generally water temperature is influenced by air temperature and intensity of solar radiations. Rawat et al. (1995) have obtained strong positive significant correlation between air and water temperature. Bose and Gorai (1993) reported negative correlation between water temperature and dissolved oxygen.

Table 3. Seasonal variation in the physico-chemical parameters of water of Baidya fish farm (Nov., 2008-Oct., 2010)

\begin{tabular}{lcccccc}
\hline \multirow{2}{*}{ Parameters } & \multicolumn{3}{c}{ Year I } & \multicolumn{3}{c}{ Year II } \\
\cline { 2 - 7 } Air temperature ${ }^{0} \mathrm{C}$ & Winter & Summer & Rainy & Winter & Summer & Rainy \\
\hline \multirow{2}{*}{ Water temperature ${ }^{0} \mathrm{C}$} & \pm 2.449 & \pm 1.707 & \pm 1.957 & \pm 2.688 & \pm 1.701 & \pm 1.5 \\
& \pm 2.380 & \pm 2.286 & \pm 1.825 & \pm 3.50 & \pm 0.577 & \pm 0.816 \\
\hline \multirow{2}{*}{$\mathrm{pH}$} & 8.07 & 7.07 & 7.0 & 8.4 & 8.52 & 8.82 \\
& \pm 0.330 & \pm 0.865 & \pm 0.648 & \pm 0.336 & \pm 0.607 & \pm 0.02 \\
\hline \multirow{2}{*}{ TDS mg/l } & 254.75 & 251.25 & 160 & 197.75 & 255.25 & 106.25 \\
& \pm 36.188 & \pm 127.432 & \pm 26.770 & \pm 102.63 & \pm 121.041 & \pm 7.135 \\
\hline \multirow{2}{*}{$\mathrm{CO}{ }_{2} \mathrm{mg} / \mathrm{l}$} & 59.89 & 111.15 & 67.32 & 31.45 & 2.97 & 4.91 \\
& \pm 37.387 & \pm 47.427 & \pm 55.666 & \pm 33.722 & \pm 1.420 & \pm 2.775 \\
\hline \multirow{2}{*}{ DO mg/l } & 6.04 & 7.36 & 6.32 & 8.25 & 6.18 & 8.33 \\
& \pm 1.012 & \pm 0.537 & \pm 0.635 & \pm 1.564 & \pm 2.495 & \pm 2.030 \\
\hline \multirow{2}{*}{ BOD mg/l } & 1.40 & 0.91 & 2.58 & 6.87 & 1.655 & 4.34 \\
& \pm 0.900 & \pm 0.306 & \pm 1.217 & \pm 1.686 & \pm 0.19 & \pm 3.160 \\
\hline \multirow{2}{*}{ Chloride mg/l } & 15.59 & 23.18 & 11.89 & 4.75 & 4.25 & 4.5 \\
& \pm 14.127 & \pm 1.771 & \pm 9.726 & \pm 3.403 & \pm 4.272 & \pm 2.081 \\
\hline \multirow{2}{*}{ Total alkalinity mg/l } & 131.02 & 189.95 & 124.42 & 151.87 & 148.1 & 93.95 \\
& \pm 24.309 & \pm 18.090 & \pm 25.117 & \pm 64.476 & \pm 17.920 & \pm 17.937 \\
\hline \multirow{2}{*}{ Total hardness mg/l } & 113.39 & 119.05 & 95.12 & 100.44 & 128.5 & 76.23 \\
& \pm 8.298 & \pm 22.498 & \pm 10.797 & \pm 38.752 & \pm 3 & \pm 2.556 \\
\hline \multirow{2}{*}{ Ammonia mg/l } & 5.82 & 8.80 & 6.07 & 6.48 & 12.75 & 11.9 \\
& \pm 4.074 & \pm 2.465 & \pm 3.140 & \pm 3.756 & \pm 3.255 & \pm 5.375 \\
\hline \multirow{2}{*}{ Nitrate mg/l } & 0.16 & 0.001 & 0.018 & 0.001 & 0.001 & 0.001 \\
\hline \multirow{2}{*}{ Phosphate mg/l } & \pm 0.297 & \pm 000 & \pm 0.023 & \pm 0 & \pm 0 & \pm 0 \\
\hline & \pm 0.26 & 0.62 & 0.24 & 0.31 & 0.515 & 0.59 \\
& & \pm 0.188 & \pm 0.170 & \pm 0.274 & \pm 0.219 & \pm 0.408 \\
\hline
\end{tabular}

The highest $\mathrm{pH}$ was recorded in winter in the first year but the lowest in rainy season. It was due to lowering of water temperature and lack of liming on time. In second year, $\mathrm{pH}$ was higher in rainy and lower in winter season. Several workers have reported low $\mathrm{pH}$ during the low photosynthesis due to the formation of carbonic acid (Bais et al., 1995). However, 
Gautam (1990) reported highest $\mathrm{pH}$ in summer and lowest in rainy season. Rawat et al. (1995) reported positive correlation with total alkalinity.

The $\mathrm{CO}_{2}$ was higher in summer in first year and in rainy in the second year which may be due to high temperature, high rate of decomposition of organic matter, low volume of water etc. Michael (1969) stated that the concentration of carbon dioxide is directly correlated with the amount and nature of biological activities in water. Gautam (1990), and Pandey and Lal (1995) also found minimum carbon dioxide in winter season.

DO was higher in summer in the first year and in rainy in the second year. Generally, the maximum DO found in winter season may be due to low temperature. Minimum DO was found in summer due to high temperature and higher microbial demand for oxygen in decomposition of organic matter (Bhowmic \& Singh, 1985). But McColl (1972) reported that the relationship between water temperature and DO is not so significant because production and consumption of oxygen takes place simultaneously.

BOD of the present study site was higher in rainy season during first year and lowest in winter in the second year. The maximum value of BOD in summer may be due to high concentration of organic matter and minimum BOD in winter may be due to low temperature and retarded microbial activities for the decomposition of organic matters. Similar observations were made by Singh and Singh (1995).

Total hardness was higher in summer. It was due to low volume and slow current of water. Similar results were obtained by Mishra et al. (1998). Minimum quantity in rainy season may be due to more dilution of water (Patralekha, 1994).

Total alkalinity of the site was higher in summer in the first year but higher in winter in the second year (Tab. 3). Singh (1990) and Mishra et al. (1998) also reported maximum pH in winter.

Ammonia was recorded higher in summer in first and second year. Ammonia content of pond water is directly affected by $\mathrm{pH}$. With increase in $\mathrm{pH}$ values, the fraction of undissociated ammonia increases and the fraction of dissociated ammonium ions decrease. However, nitrifying bacteria could take up the ammonia even at low concentration (Yoshifomi et al., 2008).

Phosphate was recorded higher in summer during first year and in rainy season in the second year. Phosphate increases the productivity of ponds.

Chloride content was recorded maximum in summer in the first year and in winter in the second year. Chloride content indicates the presence of organic wastes of animal origin (Thresh et al., 1949). Swarup and Singh (1979) also reported an increase in chloride during summer and decrease in rainy seasons mainly due to dilution of water by rain water. On the basis of present study, the water quality of fish pond was normal except manuring period and casual addition of wastes like toilet cleaners, caustic potash etc.

Outbreak of epizootic ulcerative syndrome (EUS) were observed at periphery of Baidya fish farm due to sudden fall in temperature (more than $5^{\circ} \mathrm{C}$ ) during winter when polluted cold water from Koshi canal was added. The affected fishes developed several lesions around the body and fins. Due to sudden fall in DO less than $4 \mathrm{mg} / \mathrm{l}$ during April and May; mass 
mortality of fishes Labeo rohita, Cirrhina mrigala, Hypothalamichthys molitrix, Aristichthys nobilis occurred whereas when chicken droppings was added in pond ammonia concentration raised up to $18.7 \mathrm{mg} / \mathrm{l}$ which led to mass mortality of fish (Pangasius) during August.

\section{Acknowledgements}

One of the authors (GBT) is very thankful to UGC, Nepal for financial support to carry out the research. Sincere thanks are due to authorities of Central Campus of Technology, T.U., Dharan and SEAM-N, MMA Environmental Laboratory, Biratnagar for providing the necessary lab facilities.

\section{References}

APHA, 2005. Standard methods for examination of water and waste water. $20^{\text {th }}$ Ed., Washington, USA.

Aryal, S. \& P. Lacoul. 1996. Water quality and diversity of diatoms in Punyamati river, Nepal. Ecoprint 3: 45-49.

Bais, V.S., N.C. Agrawal \& A. Tazeen. 1995. Comparative study on seasonal changes in phytoplankton community in the Sagar lake and Military Engineering lake (M.P.). $J$. Freshwater Biol. 7: 19-25.

Bhowmik, M.L. 1988. Limnology and productivity of some Beels and Baors of West Bengal with reference to recent development. Environ. Ecol. 6: 42-48.

Bose, S.K. \& A.C. Gorai. 1993. Seasonal fluctuations of plankton in relation to physicochemical parameters of a freshwater tank of Dhanbad, India. J. Freshwater Biol. 5: 133-140.

Dobriyal, A.K. \& H.R. Singh. 1989. Observation on temporal trends of phytoplankton diversity in the river Nayar of Garhal Himalaya. J. Freshwater Biol. 1: 1-6.

DOFD. 2007. Country profile-Nepal 2006/2007. Fishery sub-sector. Directorate of Fisheries Development (DOFD), Department of Agriculture, Balaju, Kathmandu, Nepal.

Gautam, A. 1990. Ecology and pollution of Mountain waters. Ashish Publishing House, New Delhi.

Hossain, D.M., M. Kabil \& M. Rahman. 2007. Water quality parameters and incidence of fish diseases in some water bodies in Natore, Bangaladesh. J. Life Earth Sci. 2: 27-30.

Lohman, K., M.F.K. Jones, D.G. Swar, M.A. Pamperl \& B.J. Brazos. 1988. Pre and and post monsoon limnological characteristics of lakes in the Pokhara and Kathmandu valleys Nepal. Verh. Internat. Verein. Limnol. 23: 558-565.

McColl, R.H.S. 1972. Chemistry and trophic status of seven New Zealand lakes. N. Z. J. Mar. Freshwater Res. 6: 399-447.

McEachern, P. 1994. Limnology and natural wetlands survey. In: Safeguarding wetlands in Nepal (Eds. B. Bhandari, T.B. Shrestha \& P. McEachern) IUCN, Nepal. pp. 89-103.

Michael, R.G. 1969. Seasonal trends in physico-chemical factors and plankton of a freshwater fish pond and their role in fish culture. Hydrobiol. 33: 144-160.

Mishra, A.P., B.K. Bora \& M. Sharma. 1998. Investigations on the seasonal variation of certain Physico-chemical parameters of a Beel, Assam, India. J. Freshwater Biol. 10: 83-87.

Niroula, B., K.L.B. Singh, G.B. Thapa \& J. Pal. 2010. Seasonal variations in physico-chemical properties and biodiversity in Betana pond, eastern Nepal. Our Nature 8: 212-218. 
Ormerod, S.J., S.T. Buckton, P.A. Brewin, A. Jenkins, R.C. Johnson, U. Juttner \& A. Suren. 1996. Biodiversity, chemistry and structure in streams of the Nepalese Himalaya. In: Proc. Inter. Confer. Ecohydrol. High Mountain (Eds. S.R. Chalise \& N.R. Khanal), Kathmandu. pp. 1197-200.

Pandey, K.K. \& M.S. Lal. 1995. Limnological studies of Garhwal Himalayan hill stream Khandagad: Seasonal fluctuation in abiotic profile. J. Freshwater Biol. 7: 7-11.

Patralekh, L.N. 1994. Comparative account of physico-chemical properties of three freshwater ecosystems. J. Freshwater Biol. 6: 115-119.

Rawat, M.S., C.P. Juyal \& R.C. Sharma. 1995. Morphometry and physico-chemical profile of high altitude lake Deoria Tal of Garwal Himalaya. J. Freshwater Biol. 7: 1-6.

Reid, G.K. 1961. Ecology of inland water and streams. Reinhold Publication Corporation, New York.

Shrestha, J. 1994. Fishes, fishing implements and methods of Nepal (Ed. T.C. Majupuria) Pub. Smt. Gupta, M.D. Lalitpur Colony, Lashkar.

Shrestha, J. 2001. Taxonomic revision of fishes of Nepal. In: Environment and agriculture: Biodiversity, agriculture and pollution in south Asia (Eds. P.K. Jha, S.R. Baral \& S.B. Karmacharya). Ecological Society (ECOS), Kathmandu, Nepal. pp. 171-180.

Shrestha, J., D.M. Singh \& T.B. Saund. 2009. Fish diversity of Tamor river and its major tributaries of eastern Himalayan region of Nepal. Nepal Journal of Science and Technology pp. 219-223.

Shrestha, T.K. 2008. Fish diversity of Nepal and potentiality of indigenous fishes for future development of aquaculture. Workshop on Indigenous Fish Stock and Livelihood. Organised by NARC. pp. 1-20.

Singh, H.P. 1990. Distribution and seasonal fluctuation of certain physico-chemical features in the Brahmaputra river. J. Assam Sci. Soc. 32: 64-69.

Singh, R.K. \& S.P. Singh. 1995. Phyco-chemical conditions of the river Sone at Dalmianagar (Bihar). J. Freshwater Biol. 7: 93-98.

Swarup, K. \& S.R. Singh. 1979. Limnological studies on Suraha lake (Ballia). J. Inland Fish. Soc. India. 11: 22-23.

Thresh, J.C., J.F. Beale \& E.V. Suckling. 1949. The examination of water and water supplies (Ed. E.W. Taylor), J. \& A. Churchill Ltd., London.

Trivedy, R.K. \& P.K. Goel. 1984. Chemical and biological methods for water pollution studies. Environmental Publications, Karad, India.

Yoshifumi, A., N. Tatsunori, T. Reiji, Y. Kiyoshi \& T. Tatsuak. 2008. Seasonal changes in abundance of ammonium-oxidizing bacteria and their nitrification in sand of Eelgrass zone. Microbes. Environ. 24: 121-127. 